\title{
Loss of PKD1 and loss of Bcl-2 elicit polycystic kidney disease through distinct mechanisms
}

\author{
P Hughes ${ }^{1,2}$, M Robati $^{1}$, W Lư ${ }^{3}$, Z Zhou ${ }^{3}$, A Strasser ${ }^{1}$ and \\ P Bouillet ${ }^{\star, 1}$ \\ 1 The Walter and Eliza Hall Institute of Medical Research, Melbourne, Victoria \\ 3050, Australia \\ 2 Department of Medical Biology, The University of Melbourne, Parkville, Victoria \\ 3010, Australia \\ 3 Renal Division, Department of Medicine, Brigham and Women's Hospital and \\ Harvard Medical School, Boston, Massachusetts, USA \\ * Corresponding author: P Bouillet, The Walter and Eliza Hall Institute of Medical \\ Research, P.O. The Royal Melbourne Hospital, Parkville, Vic, 3050. Australia. \\ Tel: +61-3-9345-2334; Fax: + 61-3-9347-0852; \\ E-mail: bouillet@wehi.edu.au
}

Received 23.8.05; revised 06.10.05; accepted 11.10.05; published online 11.11 .05 Edited by SJ Martin

\begin{abstract}
We have recently demonstrated that ablation of one or both alleles of the proapoptotic gene Bim prevents the polycystic kidney disease (PKD) that develops in mice deficient for the prosurvival protein Bcl-2. The aim of the present study was to investigate whether loss of Bim or Bcl-2 could influence the disease in the PKD1 ${ }^{\text {del } 34 / d e / 34}$ mutant mice, a model of autosomal dominant PKD. PKD1 del34/del34 mice were intercrossed with Bim-deficient mice and $\mathrm{BCl}_{-2}{ }^{+/-}$mice to generate double mutants. Loss of Bim does not prevent the development of PKD in PKD1 ${ }^{\text {del34/del34 }}$ mice. On the C57BL/6 genetic background, most older PKD1 $1^{\text {del } 34 /+}$ mice do not develop PKD, but present with liver cysts. Surprisingly, loss of Bim completely prevented liver cysts formation in $P K D 1^{d e l 34 /+}$ mice. Loss of one $B c l-2$ allele did not influence the $P K D 1^{d e l 34}$ phenotype significantly. We conclude that loss of PKD1 and loss of Bcl-2 elicit PKD through distinct mechanisms.

Cell Death and Differentiation (2006) 13, 1123-1127.

doi:10.1038/sj.cdd.4401815; published online 11 November 2005
\end{abstract}

Keywords: Polycystic kidney disease; Bcl-2; PKD1; Bim; apoptosis

Abbreviations: PKD, polycystic kidney disease; ADPKD, autosomal dominant polycystic kidney disease; PCR, polymerase chain reaction

\section{Introduction}

Polycystic kidney diseases (PKD) are a major cause of chronic kidney disease and end-stage renal failure. ${ }^{1}$ They form a rather heterogenous group of diseases, with great variations in the age of onset and severity. Most are hereditary and due to mutations in single genes. Autosomal dominant polycystic kidney disease (ADPKD) is caused by mutations in either PKD1 or PKD2. ${ }^{2-4}$ Nephronophthisis, an autosomal recessive condition, can be caused by mutation in one of 5 genes, NPHP $1-5,{ }^{5}$ and medullary cystic disease, an autosomal dominant disease, is caused by mutations in MDCK1 or MDCK2. ${ }^{6,7}$ Most of these genes code for proteins associated with the primary cilium, a cellular organelle thought to act as a mechano- and chemo-sensor in the renal epithelium. ${ }^{8}$

Several mouse models of PKD exist. ${ }^{9}$ Some have arisen from spontaneous mutations, while others are the result of genetic manipulations through targeted or random mutagenesis.

Mutations in polycystin, the product of the PKD1 gene, account for $85-90 \%$ of all cases of ADPKD in humans. Both null and hypomorphic alleles of PKD1 have been generated by gene targeting in mice (reviewed in Guay-Woodford ${ }^{9}$ ). In all cases, the homozygous mutation leads to the death of the animals around birth, due to the development of polycystic kidneys starting around E15.5. Additional defects are observed in some of these mouse models. For example, $P K D 1^{\text {del34/+ }}$ animals may develop cysts not only in the kidney but also in the pancreas and/or liver (as in human ADPKD); this phenotype is influenced by age and genetic background. ${ }^{10,11}$ Some reports have indicated a role for polycystin in the control of apoptotic cell death, ${ }^{12}$ thereby implying that abnormal death of normally long-lived cells in the kidney may be the cause of polycystic disease in PKD1 mutant mice and humans.

The Bcl-2 family of proteins are critical regulators of apoptosis in metazoans. ${ }^{13,14}$ These proteins contain at least one of four $\mathrm{Bcl}-2$ Homology domains $(\mathrm{BH} 1-4)$. The antiapoptotic members of the family, namely $\mathrm{Bcl}-2, \mathrm{Bcl}-\mathrm{xL}, \mathrm{Mcl}-1, \mathrm{~A} 1$ and $\mathrm{Bcl}-\mathrm{w}$ all share three or four $\mathrm{BH}$ domains. The proapoptotic members Bax, Bak and Bok contain three of the $\mathrm{BH}$ domains, $\mathrm{BH} 1-3$, whereas a more distantly related group of proapoptotic proteins (including Bim, Bad, Bmf, Bid, Hrk, Bik, Noxa and Puma) contain only the BH3 domain. These so-called $\mathrm{BH} 3-$ only proteins function as essential initiators of the apoptotic cascade, each sensing a particular subset of developmentally programmed death stimuli and/or cytotoxic insults. The Bax/Bak-like proteins are also essential for apoptotic cell death and they appear to function at a point downstream of the $\mathrm{BH} 3$-only proteins. The prosurvival $\mathrm{Bcl}-2$ family members have been shown to bind to both BH3-only proteins and Bax/Bak-like proteins, but it is presently not clear whether they promote cell survival by inhibiting $\mathrm{BH} 3-o n l y$ proteins, by neutralising Bax/Bak-like proteins or by some other mechanism.

A role for members of the Bcl-2 protein family in PKD has been inferred from studies with gene-targeted mice. Although $\mathrm{Bcl}-2^{-1-}$ mice appear outwardly normal at birth, they rapidly develop PKD, fail to thrive and die within a few weeks. ${ }^{15-17}$ On the C57BL/6 genetic background, the average age of death is $\sim 4-5$ weeks. ${ }^{18}$ We have shown that loss of a single allele of the gene encoding the proapoptotic $\mathrm{BH}$-only protein Bim is sufficient to restore the development of normal kidneys in 
$\mathrm{BCl}^{-2} \mathrm{2}^{-1-}$ mice and permanently prevent $\mathrm{PKD}$ in these animals. ${ }^{18}$ We have been able to reproduce this result by downregulating Bim in vivo by using RNA interference. ${ }^{19}$ These observations demonstrated that unopposed proapoptotic activity of Bim causes the fatal PKD in $\mathrm{Bcl}-2^{-1-}$ mice.

In order to determine whether Bim may be involved in other types of PKD, we have now crossed the $\mathrm{Bim}^{-/-}$mice with the $P K D 1^{\text {del34 }}$ mice and generated doubly deficient animals (DKO). In contrast to the results obtained with the mice lacking both Bim and Bcl-2, loss of one or both alleles of Bim failed to prevent the development of PKD in PKD1 del34 mice. Moreover, detailed histological comparisons suggest that the polycystic diseases seen in $B c /-2^{-/-}$and $P K D 1^{-/-}$mice have a different origin.

\section{Results and discussion}

\section{Loss of Bim does not prevent PKD in PKD1 $1^{\text {del34 }}$ mice}

Heterozygous $P K D 1^{\text {del34/+ }}$ mice were intercrossed with Bimdeficient mice (266del strain) to determine whether loss of Bim could prevent the death due to the development of PKD

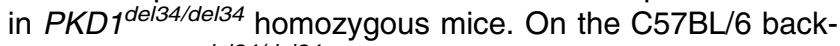
ground, $P K D 1^{\text {del34/del34 }}$ E18.5 embryos were readily recognizable because they all had massive fluid accumulation and oedema (Figure 1). $\mathrm{Bim}^{+/-} / \mathrm{PKD} 1^{\text {del34/del34 }}$ and $\mathrm{Bim}^{-1-} /$ $P K D 1^{\text {del34/del34 }}$ animals also died around birth with a phenotype indistinguishable from that of the PKD1 del34/del34 mice. Their kidneys were enlarged and contained numerous cysts at E19.5 (Figure 2, and data not shown). Thus, decreasing or ablating the expression of Bim does not prevent the development of PKD in PKD1 $1^{\text {de/34/de/34 }}$ mice, although it can prevent that arising in the $\mathrm{BCl}-2^{-1-}$ mice. This observation indicates that the diseases observed in these two mouse models differ in their origin.

PKD1 del34/+ heterozygous mice have been shown to develop renal and hepatic cysts relatively late in life $(\sim 1$ year or more) ${ }^{20}$ In order to determine whether the ablation of Bim would delay the time of onset or the severity of the disease in del34/+ heterozygous mice, we created and aged cohorts of mice with the following genotypes: $\mathrm{Bim}^{+/+} / P K D 1^{\text {del34/+} \text {, }}$ $\mathrm{Bim}^{-/-} / \mathrm{PKD} 1^{+/+}$and $\mathrm{Bim}^{-/-} / P K D 1^{\text {del34/+}}$. To check
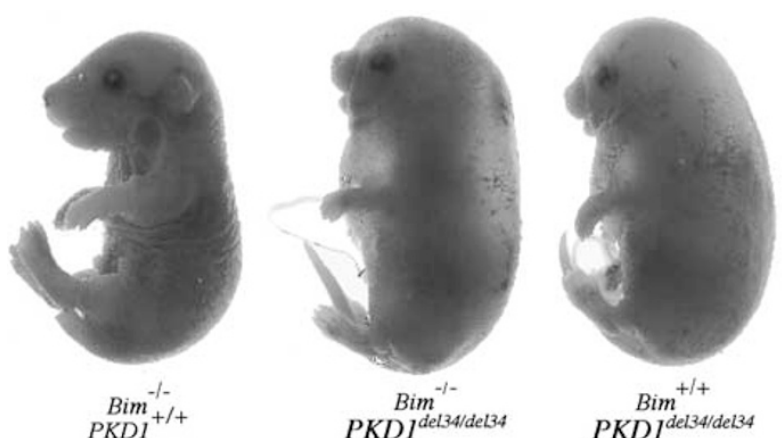

Figure 1 Loss of Bim does not rescue polycystic kidney disease in $P K D 1^{\text {del/34/del/34 }}$ mice. Bim ${ }^{-1-} / P K D 1^{\text {del/34/de/34 }}$ newborn mice display the same phenotype as $\mathrm{Bim}^{+1+} / P K D 1^{\text {del/34/del34 }}$ pups

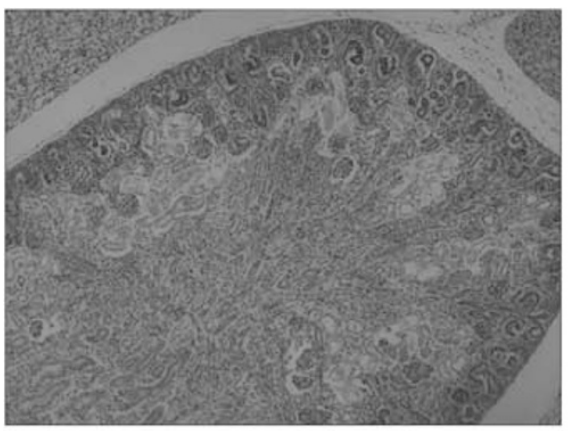

$\mathrm{Bim}^{+/+} / \mathrm{PKDI}^{+/+}$

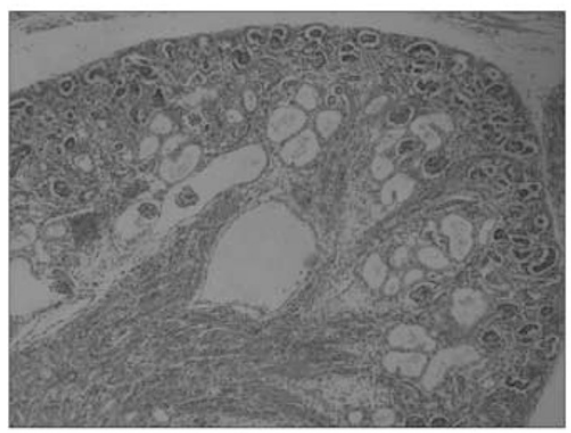

$\mathrm{Bim}^{-/-} / P K D I^{\text {del34didel34 }}$

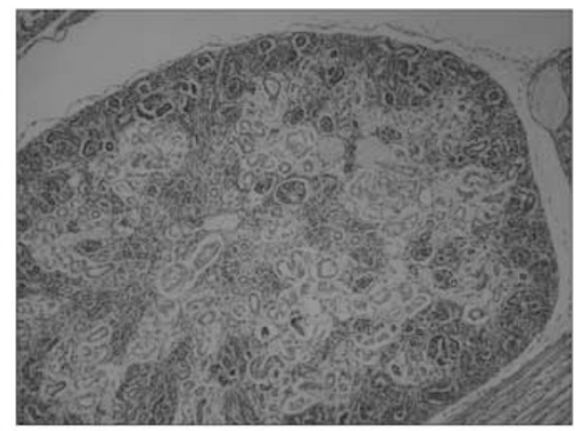

Bim $^{-/-} / \mathrm{PKDI}^{+/+}$

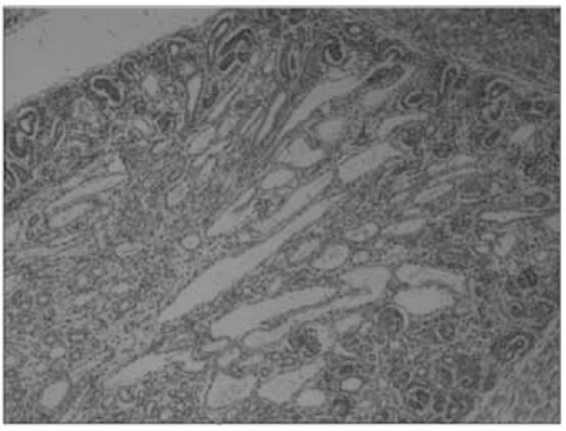

$\mathrm{Bim}^{+/+} / \mathrm{PKDI}^{\text {del34idele } 4}$

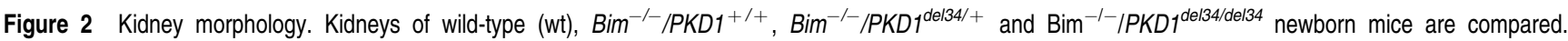
Magnification $\times 50$ 
whether loss of one allele of $\mathrm{Bcl}-2$ could exacerbate the severity of the PKD1de/34/+ phenotype, $29 \mathrm{BCl}-2^{+/-} /$ $P K D 1^{\text {de/34/ }+}$ mice were also included in this study. All these mice were killed at 16-22 months of age and their livers and kidneys sectioned to examine for the presence of cysts (Table 1). Only six of $34 \mathrm{Bim}^{+/+} / P K D 1^{\text {del34/+}}$ mice had cysts or dilated tubules in either kidney. Of the $12 \mathrm{Bim}^{+1+}$ $P K D 1^{\text {de/34/+ }}$ mice that were over 20 months of age, only one had a small cyst in one kidney and none had the large number of cysts reported for mice of that age. ${ }^{20}$ This lower incidence could reflect a difference in the genetic background of the mice in the two studies. Loss of one or both alleles of Bim did not decrease the incidence of kidney cysts in PKD1 $1^{\text {del34/+ }}$ mice, as four out of the $22 \mathrm{Bim} / P K D 1^{\text {del34/+ }}$ mice exhibited some cysts or dilated tubules. In addition, loss of one allele of $\mathrm{BCl}-2$ did not increase the severity or incidence of PKD significantly, as three of $29 \mathrm{Bcl}-2^{+/-} / P K D 1^{d e / 34 /+}$ were affected. Most kidneys from older $\mathrm{Bim}^{-1-}$ mice contained large lymphocyte infiltrates, a feature only rarely observed in mice of the other genotypes (Figure 3 ). This feature was independent of PKD1, since both $\mathrm{Bim}^{-/}$/ $P K D 1^{\text {del34/+ }}$ and $\mathrm{Bim}^{-/-} / P K D 1^{+/+}$kidneys presented it.

Our cohort of compound mutant mice was also analysed for the appearance of liver cysts (Table 1). From 1 to10 liver cysts were found in 25 of $34(73.5 \%) \mathrm{Bim}^{+/+} / P K D 1^{\text {del34/+}}$ and 14 of $29(48.3 \%) \mathrm{Bcl}-2^{+/-} / P K D 1^{\text {del34/+ }}$ mice. The cysts, how-

Table 1 Analysis of renal and liver cyst incidence in older mice of the indicated genotypes

\begin{tabular}{lllllr}
\hline & \multicolumn{2}{c}{ Kidney cysts } & & \multicolumn{2}{c}{ Liver cysts } \\
\cline { 2 - 3 } & Yes & No & & Yes & No \\
\hline bim $^{+/+} P K D 1^{+/-}$ & 6 & 28 & & 25 & 9 \\
bim $^{-/-} P K D 1^{+/-}$ & 4 & 18 & & 0 & 22 \\
bim $^{-/-} P K D 1^{+/+}$ & 1 & 18 & & 0 & 19 \\
$b c l-2^{+/-} P K D 1^{+/-}$ & 3 & 26 & & 14 & 15 \\
\hline
\end{tabular}

Incidence of kidney and liver cysts in the mice of the indicated genotypes. All the mice considered here were aged 16-22 months ever, were not as big as those previously described (the biggest cysts in our animals were $7 \mathrm{~mm}$ in diameter). This apparent reduction of liver cyst incidence found in the absence of one allele of $\mathrm{Bcl}-2$ was, however, not statistically significant (Fisher's exact test $P$-value $=0.068$ ). By contrast, none of the $28 \mathrm{Bim}^{-/-} / P K D 1^{\text {del34/+}}$ mice had liver cysts, suggesting that the absence of Bim completely prevents the development of liver cysts in $P K D 1^{\text {del34/+ }}$ mice (FET $P=0.00007)$.

In summary, the development of renal cysts in heterozygous $P K D 1^{\text {del34/+ }}$ mice appears less severe on the C57BL/ 6 background than it is on a mixed 129Sv/ C57BL/6 or 129Sv/ BALB/c background, and it is not affected by the loss of one or both alleles of Bim or loss of one allele of $B c /-2$. In contrast, the absence of Bim prevents the development of liver cysts.

\section{Differences between $\mathrm{BCl}-2^{-I-}$ and $P K D 1^{d e / 34 / d e / 34}$ kidneys}

Since all our mice were on the same genetic background and thus directly comparable, we harvested wt, $\mathrm{BCl}-2^{-1-}$ and $P K D 1^{\text {de/34/de/34 }}$ kidneys at different stages of development for histological examination. The first differences could be seen at $\mathrm{E} 15.5$, when $\mathrm{Bcl}-2^{-1-}$ kidneys appeared slightly smaller

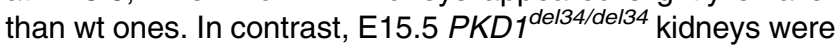
slightly larger than normal and already contained some cysts. Differences between the different mutant animals became progressively more obvious at later stages of development. At $\mathrm{E} 19.5, \mathrm{Bcl}-2^{-1-}$ kidneys were approximately four times smaller than wt kidneys, but did not display any signs of cysts, whereas $P K D 1^{\text {de/34/del34 }}$ kidneys were abnormally large due to the presence of numerous tubular and peri-glomerular cysts (Figure 4). At birth $\mathrm{Bcl}-2^{-1-}$ newborn are outwardly indistinguishable from wt pups, and become growth-retarded only 1 week later, while all $P K D 1^{\text {de/34/de/34 }}$ pups die at birth with a severe polycystic kidney phenotype. These anatomical differences further indicate that the diseases observed in the $\mathrm{BCl}-2^{-/-}$and the PKD1 $1^{\text {del/34/de/34 }}$ mice are of distinct origin.
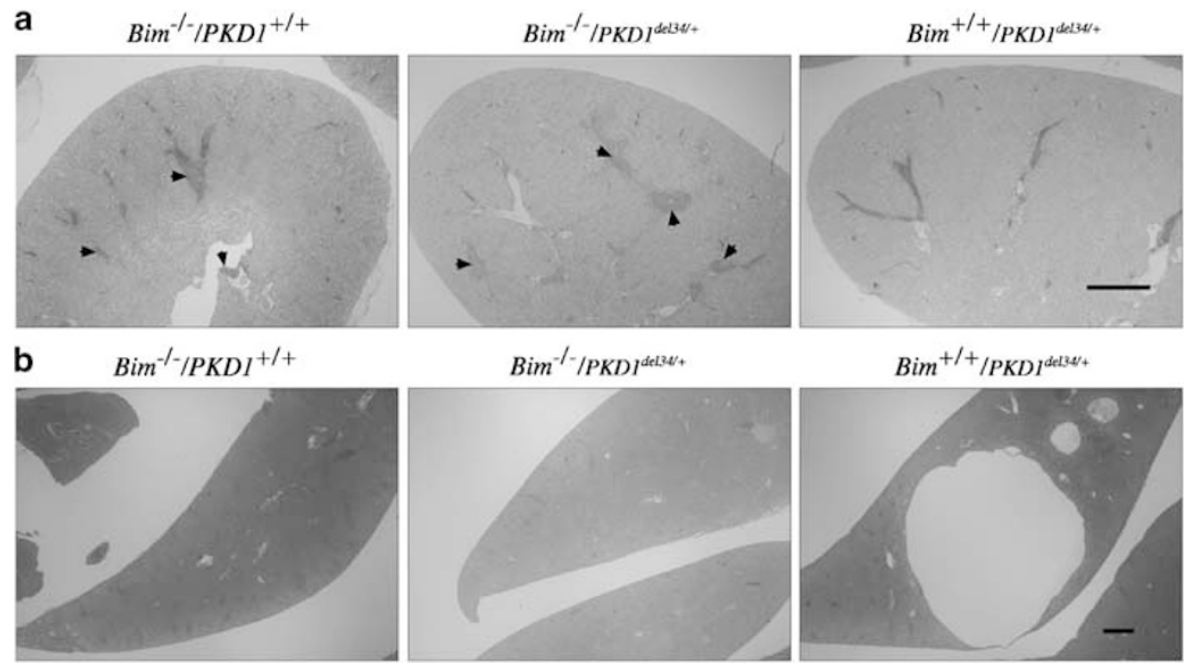

Figure 3 Older Bim and PKD1 del34 mice. (a) Kidneys of all 14-16 month-old Bim ${ }^{-1-}$ mice present with lymphocyte infiltrates rarely seen in the other genotypes considered here. Bar, $1 \mathrm{~mm}$. (b) Unlike Bim ${ }^{+/+} / P K D 1^{\text {del } 34+/-}$ mice, Bim ${ }^{-/-} / P K D 1^{\text {del } 34+/-}$ and $\mathrm{Bim}^{-/-} / \mathrm{PKD} 1^{+/+}$do not develop liver cysts upon ageing. Bar, $1 \mathrm{~mm}$ 

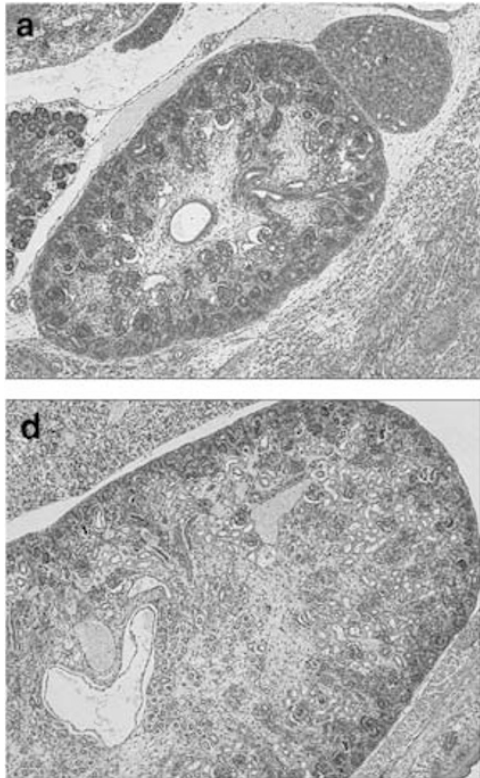

wt
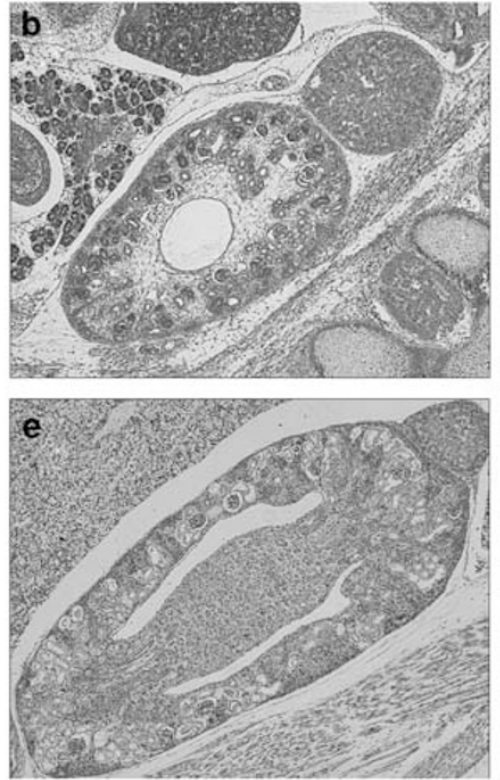

$\mathrm{BCl}-2^{-1-}$
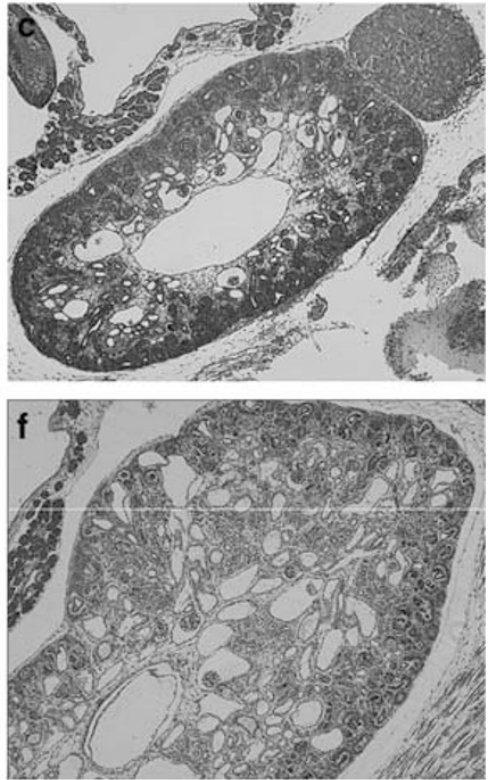

$P K D 1^{\text {deladidel34 }}$

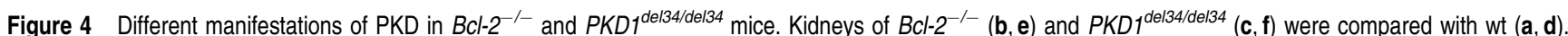
Haematoxylin/eosin-stained kidney sections of E15.5 embryo (a-c) and newborn mice (d-f). Bcl-2 ${ }^{-1-}$ kidneys are smaller but do not show any cyst at birth, whereas $P K D 1^{d e / 34 / d / 34}$ kidneys are larger and show cysts throughout development. Magnification $\times 50$

Several genes responsible for different forms of PKD have been identified recently. ${ }^{21}$ Interestingly, most of these genes appear to code for proteins which seem to directly interact or form complexes with polycystin, the product of the PKD1 gene. Polycystin is found in cells at the basal surface in focal adhesion complexes, at the lateral surface in cell adherens junctions, and in the apical primary cilium facing the lumen. ${ }^{8}$ Polycystin-containing complexes are thought to perform a mechano-sensory function in the primary cilia of renal epithelial cells, and possibly at the site of cell-matrix and cell-cell interactions. Although PKDs are heterogenous with regard to their severity and time of onset, it is possible that they are all due to abnormalities in the same signal transduction pathway involving polycystin, as all the proteins involved have been reported to interact with components of this pathway.

The disease in $\mathrm{BCl}_{-} 2^{-1-}$ mice is clearly due to excessive cell death during kidney development, and appears to be mediated primarily by the un-opposed proapoptotic activity of the BH3-only protein Bim. ${ }^{18}$ Indeed, removal of a single allele of Bim was sufficient to prevent PKD in the $\mathrm{Bcl}-2^{-1-}$ mice. None of the $\mathrm{BCl}-2^{-1-} / \mathrm{Bim}^{+1-}$ mice that have lived for 2 years has developed kidney cysts, and their kidneys are normal in size. Although several studies have reported abnormally persistent apoptosis in both autosomal dominant and autosomal recessive PKD, ${ }^{22-24}$ our results indicate that Bim probably has no role in this phenomenon in ADPKD. However, the apparent involvement of Bim in the development of liver cysts in heterozygous $P K D 1^{\text {del/34/+ }}$ mice is intriguing. The mechanism of protection offered by the loss of Bim is not clear, but it may be due to abnormally long lifespan of hepatocytes, which might reduce the risk of acquiring mutations in the wt PKD1 allele (which is probably a prerequisite for cyst development).
It is not clear whether $\mathrm{BCl}-2^{-1-}$ mice represent a suitable model for any of the reported human PKDs. Although some of the clinical manifestations appear similar to those of nephronophtisis (bilaterally shrunken kidneys, age of onset), some features are radically different (e.g. position of cysts, absence of fibrosis in $\mathrm{BCl}-2^{-1-}$ kidneys).

We observed some differences between our results on $P K D 1^{\text {del/34/+ }}$ mice and observations reported earlier. ${ }^{20}$ It appears likely that this is a reflection of a difference in the genetic bakground of the mice used in the two studies. Genetic background seems to greatly influence the development of PKD. For example, PKD in $\mathrm{BCl}_{-2}{ }^{-1-}$ mice is much more severe on an inbred C57BL/6 background than on a mixed C57BL/6/129Sv background. ${ }^{15,18}$ On the contrary, the disease in pcy mice is more severe on a DBA background than on C57BL/ 6 background. ${ }^{10}$

Does cilial dysfunction underlie all forms of cystic renal disease, as was recently suggested? Although the link between defective apoptosis and cilial dysfunction does not seem obvious, the cause of development of PKD in $\mathrm{Bcl}-2^{-1-}$ mice may be the transduction of an abnormal signal through the cilium. Indeed, the main feature of $B \mathrm{Cl}-2^{-1-}$ kidneys is their small size and their abnormally low number of nephrons. It is possible that such small kidneys may be overwhelmed soon after birth, and that the stress due to overload may be sensed and signalled through the cilium and thereby lead to the formation of cysts.

\section{Materials and Methods}

\section{Mice}

The generation of $\mathrm{Bim}^{-1-25} \mathrm{BCl}-2^{-1-16}$ and $\mathrm{PKD} 1^{\text {del3426 }}$ mutant mice has been described. The del34 mutation is a truncation that mimics many 
mutations seen in ADPKD patients, but is not equivalent to a complete ablation of the PKD1 gene. ${ }^{27}$ All the mice have been backcrossed for more than eight generations onto the $\mathrm{C} 57 \mathrm{BL} / 6$ genetic background prior to use in this study. Mice were intercrossed to generate the different genotypes described in this report.

\section{PCR genotyping}

Mice were genotyped by polymerase chain reaction (PCR) on tail DNA with the primers listed below.

For Bim mice, a three primer PCR reaction was carried out with PB20 5'-GGGATCTGGTAGCAAAGGGCCAG-3', PB65 5'-CTCAGTCCATT CATCAACAG-3', and PB335 5'-GTGCTAACTGAAACCAGATTAG-3'. For $P K D 1^{\text {del } 34}$ mice, the mutated allele could be detected by a reaction with primers neo2 $5^{\prime}$-CATACTTCAGAAGAACTCGTCAAG- $3^{\prime}$ and neo3 5'-GATTGAACAAGATGGATTGCAC-3', while wild-type (wt) allele was detected with primers PB425 5'-GAATTCAAGGTACCAAGTGT-3' and PB427 5'-CCAGACCAAGTCCTTGAGGT- $3^{\prime}$. In Bcl-2 mice, the wt allele was detected using primers PB191 5'-ATGTATGTACTTCATCACGAT-3 and PB142 5'-GACCCAATCTGGAAACCCTCCTGAT-3', and the mutated allele was detected with PB144 $5^{\prime}$-ATTCGTTCTCTTTATACTAC CAAGG-3' and PB 145 5'-TGCTAAAGCGCATGCTCCAGACTG-3'. Al the $\mathrm{PCR}$ reactions were 30 cycles $\left(94^{\circ} \mathrm{C} 40 \mathrm{~s}, 55^{\circ} \mathrm{C} 30 \mathrm{~s}, 72^{\circ} \mathrm{C} 1 \mathrm{~min}\right)$.

\section{Acknowledgements}

We thank Dr. A Harris and Professor JM Adams for helpful discussions, S Mihajlovic, E Tsui and M Chavez for histology, K Pioch and G Siciliano for animal care. This work was supported by National Health and Medical Research Council (Canberra) Grants 222099 and 257502, National Cancer Institute Grant CA43540. PB was supported by a Sylvia and Charles Viertel Senior Medical Fellowship.

\section{References}

1. Wilson PD (2004) Polycystic kidney disease. N. Engl. J. Med. 350: 151-164

2. (1994) The polycystic kidney disease 1 gene encodes a $14 \mathrm{~kb}$ transcript and lies within a duplicated region on chromosome 16. The European Polycystic Kidney Disease Consortium. Cell 78: 725

3. (1994) The polycystic kidney disease 1 gene encodes a $14 \mathrm{~kb}$ transcript and lies within a duplicated region on chromosome 16. The European Polycystic Kidney Disease Consortium. Cell 77: 881-894

4. Mochizuki T, Wu G, Hayashi T, Xenophontos SL, Veldhuisen B, Saris JJ, Reynolds DM, Cai Y, Gabow PA, Pierides A, Kimberling WJ, Breuning MH, Deltas CC, Peters DJ and Somlo S (1996) PKD2, a gene for polycystic kidney disease that encodes an integral membrane protein. Science 272: 1339-1342

5. Saunier S, Salomon R and Antignac C (2005) Nephronophthisis. Curr. Opin. Genet. Dev. 15: 324-331

6. Hart TC, Gorry MC, Hart PS, Woodard AS, Shihabi Z, Sandhu J, Shirts B, Xu L, Zhu H, Barmada MM and Bleyer AJ (2002) Mutations of the UMOD gene are responsible for medullary cystic kidney disease 2 and familial juvenile hyperuricaemic nephropathy. J. Med. Genet. 39: 882-892

7. Wolf MT, Karle SM, Schwarz S, Anlauf M, Glaeser L, Kroiss S, Burton C, Feest $T$, Otto $E$, Fuchshuber A and Hildebrandt $F$ (2003) Refinement of the critical region for MCKD1 by detection of transcontinental haplotype sharing. Kidney Int. 64: 788-792

8. Nauli SM and Zhou J (2004) Polycystins and mechanosensation in renal and nodal cilia. Bioessays 26: 844-856

9. Guay-Woodford LM (2003) Murine models of polycystic kidney disease: molecular and therapeutic insights. Am. J. Physiol. Renal. Physiol. 285: F1034-F1049

10. Nagao $\mathrm{S}$, Hibino $\mathrm{T}$, Koyama $\mathrm{Y}$, Marunouchi $\mathrm{T}$, Konishi $\mathrm{H}$ and Takahashi $\mathrm{H}$ (1991) Strain difference in expression of the adult-type polycystic kidney disease gene, pcy, in the mouse. Jikken Dobutsu 40: 45-53

11. Fain PR, McFann KK, Taylor MR, Tison M, Johnson AM, Reed B and Schrier RW (2005) Modifier genes play a significant role in the phenotypic expression of PKD1. Kidney Int. 67: 1256-1267

12. Boletta A, Qian F, Onuchic LF, Bhunia AK, Phakdeekitcharoen B, Hanaoka K, Guggino W, Monaco L and Germino GG (2000) Polycystin-1, the gene product of PKD1, induces resistance to apoptosis and spontaneous tubulogenesis in MDCK cells. Mol. Cell. 6: 1267-1273

13. Huang DCS and Strasser A (2000) BH3-only proteins - essential initiators of apoptotic cell death. Cell 103: 839-842

14. Adams JM (2003) Ways of dying: multiple pathways to apoptosis. Genes Dev. 17: $2481-2495$

15. Veis DJ, Sorenson CM, Shutter JR and Korsmeyer SJ (1993) Bcl-2-deficient mice demonstrate fulminant lymphoid apoptosis, polycystic kidneys, and hypopigmented hair. Cell 75: 229-240

16. Nakayama K, Nakayama K-I, Negishi I, Kuida K, Sawa H and Loh DY (1994) Targeted disruption of bcl-2ab in mice: occurrence of gray hair, polycystic kidney disease, and lymphocytopenia. Proc. Natl. Acad. Sci. USA 91: 37003704

17. Kamada S, Shimono A, Shinto Y, Tsujimura T, Takahashi T, Noda T, Kitamura $\mathrm{Y}$, Kondoh $\mathrm{H}$ and Tsujimoto $\mathrm{Y}$ (1995) bcl-2 deficiency in mice leads to pleiotropic abnormalities: accelerated lymphoid cell death in thymus andspleen, polycystic kidney, hair hypopigmentation, and distorted small intestine. Cancer Res. 55: 354-359

18. Bouillet $P$, Cory S, Zhang L-C, Strasser A and Adams JM (2001) Degenerative disorders caused by $\mathrm{Bcl}-2$ deficiency are prevented by loss of its $\mathrm{BH} 3-$ only antagonist Bim. Dev. Cell 1: 645-653

19. Bouillet $P$, Robati M, Bath $M$ and Strasser $A$ (2005) Polycystic kidney disease prevented by transgenic RNA interference. Cell. Death Differ. 12: 831-833

20. Lu W, Fan X, Basora N, Babakhanlou H, Law T, Rifai N, Harris PC, PerezAtayde AR, Rennke HG and Zhou J (1999) Late onset of renal and hepatic cysts in Pkd1-targeted heterozygotes. Nat. Genet. 21: 160-161

21. Wilson PD (2004) Polycystic kidney disease: new understanding in the pathogenesis. Int. J. Biochem. Cell. Biol. 36: 1868-1873

22. Woo D (1995) Apoptosis and loss of renal tissue in polycystic kidney diseases. N. Engl. J. Med. 333: 18-25

23. Ecder T, Melnikov VY, Stanley M, Korular D, Lucia MS, Schrier RW and Edelstein CL (2002) Caspases, Bcl-2 proteins and apoptosis in autosomaldominant polycystic kidney disease. Kidney Int. 61: 1220-1230

24. Tao Y, Kim J, Stanley M, He Z, Faubel S, Schrier RW and Edelstein CL (2005) Pathways of caspase-mediated apoptosis in autosomal-dominant polycystic kidney disease (ADPKD). Kidney Int. 67: 909-919

25. Bouillet $P$, Metcalf $D$, Huang DCS, Tarlinton DM, Kay TWH, Köntgen $F$, Adams JM and Strasser A (1999) Proapoptotic Bcl-2 relative Bim required for certain apoptotic responses, leukocyte homeostasis, and to preclude autoimmunity. Science 286: 1735-1738

26. Lu W, Peissel B, Babakhanlou H, Pavlova A, Geng L, Fan X, Larson C, Brent G and Zhou J (1997) Perinatal lethality with kidney and pancreas defects in mice with a targetted Pkd1 mutation. Nat. Genet. 17: 179-181

27. Lu W, Shen X, Pavlova A, Lakkis M, Ward CJ, Pritchard L, Harris PC, Genest DR, Perez-Atayde AR and Zhou J (2001) Comparison of Pkd1-targeted mutants reveals that loss of polycystin-1 causes cystogenesis and bone defects. Hum. Mol. Genet. 10: 2385-2396 